\title{
DAMPAK COVID-19 TERHADAP KUALITAS AUDIT PERUSAHAAN
} (STUDI LITERATUR)

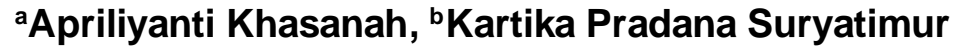 \\ a,b Universitas Tidar Magelang \\ apriliyantikhasanah@gmail.com
}

\begin{tabular}{l|l|l} 
Received : September & Accepted : October & Published: December
\end{tabular}

\begin{abstract}
ABSTRAK
Dampak covid-19 terhadap kualitas audit perusahaan. Penelitian ini dilakukan dengan tujuan untuk menganalisis dampak dari adanya pandemi Covid-19 terhadap kualitas audit suatu perusahaan. Peneliti menggunakan metode kualitatif dengan kajian literature untuk menganalisis kemungkinan dampak Covid-19 pada kualitas audit termasuk biaya audit, penilaian going concern, prosedur audit, dan sumber daya auditor. Berdasarkan hasil analisis yang dilakukan, adanya penurunan biaya audit, tantangan terhadap penilaian going concern, dan kemungkinan kehilangan staf auditor yang terserang corona berpengaruh terhadap kualitas audit suatu perusahaan. Oleh sebab itu, auditor harus berinvestasi lebih pada bidang teknologi seperti blockchain, kecerdasan buatan dan juga keamanan jaringan, serta perlunya untuk mencermati standar audit yang relevan digunakan pada kondisi saat ini.
\end{abstract}

Kata kunci: Covid-19, Kualitas Audit, Opini audit

\section{ABSTRACT}

The impact of covid-19 on the quality of company audits. This study was conducted with the aim of analyzing the impact of the covid-19 pandemic on the audit quality of a company. Researches used a qualitative methode with a literature review to analyze the possible impact of covid-19 on audit quality including audit fees, going concern assessments, audit procedures, and auditor resources. Based on the result analysis carried out, a decrease in audit fees, challenges to going concern assessments, and the possibility of losing auditor staff to the corona virus effect the audit quality of a company. Therefore, auditors should invest more in technology areas such as blockchain, artificial intelligence and network security, as well as the need to pay close attention to the relevant auditing standars used in the current situation.

Keywords: Covid-19, Audit Quality, Audit Opinion

\section{PENDAHULUAN}

Wabah virus corona yang muncul pertama kali di Wuhan pada tahun 2019 telah dengan cepat menyebar ke seluruh dunia, bahkan telah menyebar ke 200+ negara di segala penjuru yang menyebabkan terjadinya kemerosotan di bidang ekonomi secara universal. Berdasarkan data Coronavirus Resource Center John Hopkins University \& Medicine (JHU 2021), per 3 September 2021 total kasus corona di dunia telah menyentuh angka 218.969.254 kasus, dengan total kematian sebanyak 4.550.984 jiwa. Maraknya wabah Penyakit Coronavirus 19 (Covid-19) membuat khawatir seluruh dunia. Pasalnya, tidak hanya mengakibatkan kegentingan pada kesehatan, tetapi juga pada bidang ekonomi maupun pendidikan.

Dengan meningkatnya kasus virus corona yang terjadi setiap hari, tentu berimbas terhadap banyak hal, tak terkecuali pada praktik auditor yang tidak berjalan mulus. Sebagai tindak lanjut dari peningkatan wabah virus corona yang terus melejit ini, pemerintah 
menerapkan pemberlakuan Pembatasan Sosial Berskala Besar (PSBB) dengan maksud untuk mengurangi persebaran virus corona. Namun disisi lain, dengan diberlakukannya PSBB justru berdampak pada proses audit yang dilakukan oleh auditor. Pemberlakuan PSBB membuat segala aktivitas di luar rumah berkurang, bahkan tidak sedikit pula perusahaan yang mengalami pemblokiran total sehingga dalam situasi seperti ini membuat auditor mengalami kesulitan terutama dalam hal akses pengumpulkan bukti audit. Sementara itu, meskipun berada pada situasi seperti sekarang ini, auditor tetap harus mendapatkan bukti audit yang memadai dan akurat sebagai pendukung dari pernyataan audit yang diberikan, sebab seorang auditor selalu dituntut untuk memperhatikan kualitas audit. Adanya ketidakpastian yang tinggi pada perekonomian baik mikro ataupun makro, serta pemberlakuan PSBB membuat kepercayaan masyarakat terkait kualitas hasil audit dipertanyakan.

Menurut (KPMG 2020) dengan adanya perubahan ekonomi yang tidak dapat diprediksi ini, tentu dapat berpengaruh pada kepercayaan pemilik modal terhadap kondisi keuangan perusahaan pada periode tersebut, dan akhirnya dapat mengakibatkan berbagai masalah keuangan bagi perusahaan. Meningkatnya risiko investasi dan biaya modal ekuitas suatu perusahaan dapat diakibatkan karena kurangnya kepercayaan pemegang saham terhadap angka yang dilaporkan, hal ini terjadi apabila suatu perusahaan tidak memastikan yang terbaik untuk kualitas dari prosedur audit yang dijalankan, karena secara signifikan kualitas seorang auditor dalam mendeteksi adanya kesalahan informasi dalam laporan keuangan dipengaruhi oleh kualitas dari proses audit yang telah dilaksanakan (Albitar 2020).

Sebagai tindak lanjut dari adanya pandemi, Institut Akuntan Publik Indonesia (IAPI) menerbitkan Technical Newflash pada bulan April 2020 sebagai tanggapan auditor atas pandemi Covid-19 yang melanda. Selain IAPI, pada bulan Maret 2020 Financial Reporting Council (FRC) juga menerbitkan sebuah pemberitahuan khusus bagi auditor berkenaan dengan dampak Covid-19 terhadap kualitas audit yang berisi pedoman mengenai persoalan apa saja yang semestinya ditelaah terkait dengan imbas dari adanya pembatasan soaial pada kualitas audit (FRC 2020). Sebagai organisasi yang memiliki tanggung jawab untuk melakukan pengembangan dan penyusunan mengenai SAK, Ikatan Akuntansi Indonesia (IAI) juga melakukan penerbitan press release sebagai penyesuaian standar akuntansi akibat efek dari adanya wabah virus corona terhadap penerapan PSAK 68, PSAK 8, PSAK 71, dan ISAK 102(KPAP 2021).

Berdasarkan penelitian (Suwandi 2021) munculnya pandemi mempengaruhi kualitas audit yang disebabkan karena adanya penurunan biaya audit, tantangan dalam asesmen going concern, rendahnya tingkat keandalan bukti audit, adanya pengurangan gaji karyawan dan personel audit. Hasil penelitian ini juga mendukung penelitian sebelumnya yang dilakukan oleh (Albitar 2020). Pada sesi selanjutnya akan disajikan mengenai kajian literatur diikuti dengan penjelasan dari metode, kemudian dijelaskan mengenai analisis dan hasil dari penelitian, dan terakhir disimpulkan.

Adapun rumusan masalah dari penelitian ini yaitu aspek apa saja yang terdampak Covid19 dan berpengaruh terhadap kualitas audit laporan keuangan yang dilakukan oleh auditor Kantor Akuntan Publik. Oleh sebab itu, tujuan peneliti melakukan penelitian ini adalah untuk mengidentifikasi aspek apa saja yang terdampak Covid-19 dan berpengaruh terhadap kualitas audit sehingga dapat mengantisipasi kemungkinan dampak yang terjadi.

\section{KAJIAN LITERATUR}

\section{Kualitas Audit}

Menurut Rosnidah dalam kualitas audit merupakan kesesuaian antara standar audit dengan praktik audit yang dijalankan sehingga dapat digunakan untuk mengungkapkan dan melaporkan jika tejadi pelanggaran yang dilakukan oleh klien. Berdasarkan SPAP (2011) audit yang dilakukan oleh auditor dikatakan memiliki kualitas apabila ketentuan mengenai standar auditing terlaksana. Standar audit yang tercantum dalam Standar Pofesional Akuntan Publik yaitu sebagai berikut:

Standar Umum: (1) Audit wajib dilakukan oleh orang yang ahli dan memiliki pengalaman yang cukup sebagai auditor. (2) Auditor harus tetap bersikap independen dalam hal apapun 
yang masih memiliki hubungan dengan perjanjian. (3) Auditor harus cermat dan seksama dalam melakukan audit dan penyusunan laporan atas hasil temuannya. Standar Pekerjaan Lapangan: (1) Pekerjaan audit harus direncanakan secara memadai dan harus dilakukan supervisi apabila menggunakan asisten. (2) Untuk merancang proses audit dan menetapkan cakupan pemeriksaan yang akan dilaksanakan, auditor harus mempunyai pengetahuan yang memadai atas struktur pengendalian intern. (3) Auditor harus memperoleh bukti audit yang cukup dan kompeten sebagai landasan atas pernyataan audit yang diberikan. Standar Pelaporan: (1) Laporan audit harus menerangkan tentang kesesuaian antara laporan keuangan dengan standar akuntansi yang berlaku di Indonesia. (2) Laporan auditor harus menunjukan, jika dalam pembuatan laporan keuangan periode berjalan terdapat ketidaksesuaian antara implementasi prinsip akuntansi jika dipadankan dengan pelaksanaan prinsip akuntansi tersebut pada periode sebelumnya. (3) Dalam laporan keuangan, pengungkapan informatif harus memandai, kecuali apabila dinyatakan lain dalam laporan audit. (4) Laporan audit harus berisi opini mengenai laporan keuangan secara keseluruhan atau asersi bahwa pernyataan tersebut tidak dapat diberikan. Apabila opini secara keseluruhan tidak dapat diberikan, maka harus dinyatakan alasannya. Laporan auditor juga harus berisi mengenai petunjuk yang jelas perihal sifat pekerjaan audit yang dilakukan dan tingkat tanggung jawab auditor.

\section{Fee Audit}

Fee audit atau biaya audit merupakan sejumlah upah yang diperoleh oleh Kantor Akuntan Publik dari perusahaan klien atas jasa pemeriksaan laporan keuangan yang telah diberikannya. Besarnya upah yang diperoleh oleh auditor dipengaruhi oleh beberapa faktor, salah satunya adalah tingginya risiko. Berdasarkan Peraturan Pengurus IAPI No. 2 Tahun 2016 dalam (BAK UII 2020) menerangkan bahwa semakin rendah biaya audit yang diberikan maka akan berakibat pada semakin tinggi kemungkinan munculnya ancaman yang berupa penyelewengan terhadap kode etik akuntan publik.

\section{Time Budget Pressure}

Time Budget Pressureadalah keadaan dimana auditor mengalami tekanan akibat adanya keterbatasan atas waktu yang ditetapkan untuk menyelesaikan proses audit yang dilaksanakan. Time budget pressure yang dilakukan oleh auditor dimaksudkan untuk menekan biaya audit agar bisa serendah mungkin sehingga biaya yang digunakan dalam pelaksanaan audit lebih efisien.

Menurut Mergheim et al dalam (Fitriyah and Dewi 2018) time budget pressure dalam audit dapat terjadi apabila anggaran waktu yang ditetapkan untuk menyelesaikan audit lebih sedikit dibandingkan dengan waktu yang sebenarnya diperlukan dan auditor mampu untuk menyelesaikannya namun waktu yang dilaporkan bukanlah waktu yang sebenarnya dimanfaatkan untuk menyelesaikan audit tersebut.

\section{Opini Going Concern}

Menurut Hany et al (2003) dalam (Kurnia and Mella 2018), going concern didefinisikan sebagai kelangsungan hidup suatu badan usaha. Going concern merupakan kemampuan suatu perusahaan untuk menjalankan kegiatan usahanya dalam periode waktu tertentu. Sedangkan opini going concern adalah opini/pendapat yang diberikan oleh auditor perihal kemampuan suatu entitas untuk menjalankan usahanya dalam jangka waktu tertentu. Tingkat kemungkinan pemberian opini audit going concern dalam proses audit akan semakin besar apabila kondisi keuangan perusahaan yang diaudit mengalami ketidakstabilan.

\section{Kualitas Auditor}

Kualitas auditor adalah kemampuan seorang auditor dalam menyelesaikan suatu audit, termasuk mendeteksi adanya penyelewengan yang terjadi pada perusahaan yang diauditnya. Oleh sebab itu, untuk meningkatkan kualitas auditor, maka perlu adanya upaya yang dilakukan sehingga kompetensi auditor dapat selalu ter-upgrade dan proses audit dapat dengan mudah terselesaikan. Menurut Ketua BPK yang dikutip dari (Setiawan 2021) sebagai upaya untuk mengembangkan kompetensi auditor, maka diperlukan adanya pelatihan dan 
pembelajaran yang dilakukan dengan bentuk berupa penugasan dan pembimbingan secara langsung.

\section{Prosedur Audit}

Prosedur audit merupakan teknik yang dipergunakan oleh auditor dalam menghimpun bukti audit, dimana pemilihan prosedur dilakukan pada saat perencanaan audit. Menurut (Jusup 2014) prosedur audit ialah arahan spesifik yang menguraikan terkait dengan bukti audit yang harus ditemukan selama prosedur audit berjalan. Dengan menerapkan prosedur auditing yang telah dipilih sebelumnya, auditor dapat memperoleh bukti audit yang nantinya dapat dimanfaatkan sebagai dasar untuk pemberian opini/pendapat atas kewajaran suatu laporan keuangan. Berikut 9 pilihan tindakan untuk mengumpulkan bukti audit yang dapat dilakukan oleh auditor menurut Abdul Halim. (1) Inspeksi terhadap dokumen dan catatan dalam bentuk kertas, elektronik, maupun media lain. (2) Inspeksi terhadap aktiva berwujud yang mencakup penyelidikan pada fisik aset. (3) Observasi atau pengamatan terhadap prosedur yang diterapkan oleh karyawan. (4) Pengajuan pertanyaan (wawancara) kepada pihak internal perusahaan baik lisan maupun tulisan. (5) Konfirmasi dari pihak ketiga. (6) Rekalkulasi atau pemeriksaan keakuratan dokumen. (7) Melakukan ulang (reperformance) atas prosedur ataupun pengendalian yang telah dilaksanakan. (8) Prosedur analitis, yaitu dengan membandingkan laporan keuangan. (9) Teknik audit berbasis komputer yang dilakukan dengan memanfaatkan software audit.

\section{Dampak terhadap Kualitas Audit}

Pandemi Covid-19yang muncul belakangan ini memberikan perubahan pada banyak hal, salah satunya membuat praktik akuntan publik mengalami kendala. Berdasarkan penelitian yang dilakukan (Saleem 2021), adanya coronavirus mempengaruhi kualitas audit di Yordania dan auditor juga mengalami kesulitan dalam mendapatkan bukti audit yang tepat dari klien akibat diberlakukannya pembatasan pergerakan dan perjalanan di negara tersebut. Selain itu, menurut (Suwandi 2021) dampak pandemi Covid-19 terhadap kualitas audit dipengaruhi oleh berbagai aturan yang dijalankan oleh pemerintah sehingga menyulitkan auditor untuk membuktikan temuan yang didapatnya saat melakukan audit.

\section{METODE PENELITIAN}

Penelitian ini menggunakan metode kajian kepustakaan (literature review). Menurut Hazibuan, Zainal A (2007), dalam literature review memuat uraian mengenai teori, temuan dan bahan penelitian lain yang didapatkan dari sumber rujukan untuk digunkaan sebagai dasar penelitian (Syafnidawaty 2020). Penelitian dengan menggunakan metode Literature review merupakan penelitian yang berhubungan dengan metode pengumpulan data yang diperoleh dari beragam sumber kesastraan (buku, jurnal ilmiah, surat kabar, internet, tesis) yang sesuai dengan bahasan yang akan dikaji.

\section{PEMBAHASAN}

Pandemi Covid-19 memberikan dampak yang sangat substansial terhadap beragam bidang, tidak terkecuali bidang ekonomi. Adanya pemberlakuan PSBB membuat berbagai perusahaan terpaksa menghentikan karyawannya bahkan tidak sedikit pula yang melakukan penutupan. Hal ini tentu berakibat pada meningkatnya pengangguran dan menyebabkan sebagian besar negara mengalami pertumbuhan ekonomi yang negatif bahkan terdapat pula negara yang menghadapi resesi ekonomi. Pada bulan Januari 2021, pertumbuhan ekonomi global diestimasi oleh IMF berada di angka -3,5 persen, sementara Bank Dunia memprediksi penurunan pertumbuhan ekonomi global menjadi 5,2 persen, berbeda dengan OECD yang memprediksi penurunan senilai minus 4,2 persen (Purwanto 2021).

\section{Dampak Covid-19 pada Fee Audit}

Adanya perubahan ekonomi tentu berdampak pada semua perusahaan baik klien ataupun perusahaan audit yang akhirnya berpengaruh pada biaya audit karena perubahan 
ekonomi tersebut mempengaruhi likuiditas, risiko, dan kinerja perusahaan (Chen et al. 2019). Fee audit merupakan fee yang diperoleh akuntan publik atau auditor setelah melakukan audit pada perusahaan klien. Besarnya fee yang didapat oleh auditor dipengaruhi oleh tingginya risiko yang dihadapi saat penugasan, seberapa kompleks jasa yang auditor berikan, tingkat kemahiran yang dibutuhkan untuk menyelesaikan proses audit, komposisi dan proporsi dari biaya KAP yang berkaitan serta berbagai pertimbangan lainnya (Halim 2018).

Munculnya pandemi membuat perusahaan mengalami penurunan laba bahkan mengalami kebangkrutan sehingga berakibat pada rendahnya tingkat likuiditas atau kesanggupan suatu perusahaan untuk memenuhi utang jangka pendek yang dimilikinya. Rendahnya tingkat likuiditas yang dilengkapi dengan sulitnya auditor dalam menilai kelangsungan usaha mengakibatkan tingkat risiko menjadi tinggi, dan hal ini membuat auditor harus meningkatkan upaya audit tambahan. Selain tingginya tingkat risiko, biaya audit juga dipengaruhi oleh adanya pemberlakuan social distancing. Seperti yang dikatakan (Chen et al. 2019) dalam (Albitar 2020) bahwa adanya pemberlakuan social distancing selama pandemi membuat auditor bekerja dari rumah sehingga berdampak pada meningkatnya jam kerja dan upaya auditor, meskipun dalam hal ini klien cenderung mulai meminta biaya audit yang lebih rendah. Adanya permintaan penurunan biaya audit oleh klien sepertinya berpengaruh pada kualitas audit. Pasalnya meningkatnya jam kerja yang membuat biaya audit lebih besar dan munculnya permintaan penurunan biaya audit merupakan hal yang tidak seimbang sehingga dapat memberikan tekanan bagi auditor dalam menyelesaikan proses audit.

Rendahnya fee audit yang diterima oleh perusahaan auditor pada akhirnya juga akan berpengaruh terhadap gaji staf audit. Menurut (Hoopes et al. 2018) dengan upah yang lebih tinggi maka akan meningkatkan produktivitas auditor baik dengan membuat motivasi untuk berupaya lebih besar ataupun menarik auditor untuk berkualitas lebih tinggi. Oleh karena itu, selain rendahnya biaya audit, gaji staf audit yang disebabkan oleh pandemi juga berpengaruh terhadap kualitas audit. Rendahnya gaji staf audit membuat motivasi auditor melemah, yang akibatnya dapat berpengaruh terhadap kualitas dari audit yang dijalankan.

\section{Dampak Covid-19 pada Time Budget Pressure}

Adanya pandemi mengakibatkan proses pelaksanaan audit berlangsung lebih lama dibandingkan dengan waktu yang biasanya dihabiskan untuk menyelesaikan proses audit sebelum adanya pandemi. Hal ini pada akhirnya berpengaruh terhadap jam kerja auditor. Peningkatan jam kerja auditor salah satunya disebabkan oleh adanya PSBB yang membuat auditor sulit dalam menghimpun bukti audit. Meskipun audit yang dijalankan memerlukan waktu yang lebih banyak, dalam hal ini auditor tetap dituntut untuk menyelesaikan proses audit sehingga tidak terjadi adanya keterlambatan penyelesaian audit (audit delay). Adanya tuntutan untuk segera menyelesaikan proses audit yang dilakukan mengakibatkan tekanan pada staf auditor yang menjalankan audit tersebut.

Adanya tekanan pada staf auditor dikhawatirkan dapat berpengaruh terhadap menurunnya kinerja auditor yang pada akhirnya akan berakibat pada berkurangnya kualitas audit. Hal ini sejalan dengan penelitian (Suryo 2017) yang dilakukan pada Kantor Akuntan Publik di Bandung dimana hasilnya membuktikan bahwa time budget pressure ternyata memiliki pengaruh terhadap kinerja auditor. Hal ini didukung oleh penelitian (Diatmika and Savitri 2020) yang meneliti dengan populasi auditor di Kantor Akuntan Publik di Wilayah Bali. Semakin terbatasnya anggaran waktu yang ditetapkan maka akan membuat tekanan pada auditor yang semakin tinggi, sehingga kualitas audit semakin menurun.

\section{Dampak Covid-19 pada Opini Going Concern}

Pandemi secara tidak langsung berpengaruh terhadap penjualan perusahaan. Banyaknya perusahaan yang mengurangi penjualan bahkan menerapkan penutupan karena dampak covid-19, tampaknya membuat auditor kesulitan dalam menilai kemampuan perusahaan untuk menjalankan usahanya dan muncul pertanyaan apakah situasi dari basis going concern sendiri saat ini masih sesuai sebagai dasar dalam penyusunan laporan keuangan atau tidak (KPMG 2020). Adanya kesulitan serta keraguan dalam menentukan opini going concern dapat berpengaruh terhadap kualitas audit. Oleh sebab itu, auditor sudah 
semestinya untuk memberikan tinjauan lebih atas kemungkinan terdapatnya pengingkaran dari kesepakatan untuk pinjaman ataupun lainnya yang kemungkinan akan muncul karena imbas dari adanya perubahan keadaan perusahaan, yang akhirnya berpengaruh terhadap penyajian klasifikasi pinjaman dan kelangsungan usaha (IAPI 2020a). Tingginya tingkat ketidakpastian menyiratkan bahwa dibutuhkannya tingkat staf audit yang sesuai sehingga dapat memberikan dukungan yang tepat dan memadai bagi auditor (KPMG 2020).

\section{Dampak Covid-19 pada Kualitas Auditor}

Menurut WHO Covid-19 merupakan penyakit menular yang diakibatkan oleh coronavirus yang dapat berakibat pada terserangnya infeksi pada saluran nafas manusia dengan gejala awal batuk pilek sampai yang lebih serius (WHO 2020). Dengan adanya covid-19 membuat proses audit menjadi terkendala. Pasalnya virus ini menyerang sebagian besar orang tidak terkecuali staf auditor. Kemungkinan adanya staf yang sakit dan karantina akibat terserang virus corona membuat berkurangnya personel dalam melakukan audit sehingga dapat berpengaruh terhadap kinerja KAP dan kualitas audit yang dijalankan. Tidak hanya itu, pandemi ini juga mengakibatkan terkendalanya program-program yang telah perusahaan audit rencanakan sebelumnya, seperti program pelatihan bulanan maupun lokakarya.

Wabah Covid-19 memaksa seluruh perusahaan audit untuk menggagalkan segala program pengembangan profesional untuk auditor seperti pelatihan bulanan dan lokakarya meskipun perusahaan audit memiliki kemauan untuk mengatur program tersebut (Deloitte 2020). Dengan adanya program pelatihan yang diselenggarakan oleh perusahaan, maka diharapkan dapat menaikkan kinerja audit yang pada akhirnya berpengaruh terhadap kualitas audit. Seperti yang dikatakan (Lennox and Wu 2018) bahwa kemahiran seseorang bisa didapatkan melalui pengalaman tidak langsung (seperti pelatihan bulanan dan lokakarya), ataupun pengalaman secara langsung seperti berinteraksi dengan klien di suatu perusahaan. Namun karena munculnya pandemi membuat segala program pelatihan dibatalkan yang berakibat kepada kemampuan auditor yang berkurang. Kurangnya kemampuan auditor pada akhirnya akan berpengaruh terhadap menurunnya kualitas audit.

\section{Dampak Covid-19 pada Prosedur Audit}

Pandemi memaksa para pekerja di seluruh perusahaan untuk bekerja dari rumah (Work From Home), tidak terkecuali auditor yang bekerja di berbagai perusahaan audit. Hal ini tentu memberikan pengaruh bagi kinerja auditor dalam melaksanakan proses audit. Namun, disisi lain auditor dituntut untuk tetap menjaga kualitas auditnya. Munculnya pandemi mengakibatkan adanya kemungkinan personel auditor yang terserang Covid-19 disertai pemberlakuan pembatasan akses jalan sehingga berdampak pada terganggunya kemampuan auditor dalam menghimpun bukti audit yang handal.

Menurut (IAPI 2020b) auditor dianjurkan untuk memelajari sedalam mungkin prosedur alternatif, termasuk dalam bidang teknologi. Secara tidak langsung, pandemi memaksa perusahaaan audit untuk berinvestasi lebih banyak pada bidang teknologi karena proses audit jarak jauh. Remote audit atau pemeriksaan jarak jauh merupakan proses penugasan audit yang dilakukan auditor dengan auditee dimana dalam proses pemeriksaan tidak dilakukan secara langsung, namun dengan menggunakan bantuan komputer dan perangkat teknologi informasi (Litzenberg and Ramirez 2020). Dengan pemeriksaan jarak jauh membuat auditor dituntut untuk mengasah keahlian dalam bidang teknologi. Pasalnya ada beberapa risiko yang harus diwaspadai ketika melaksanakan pemeriksaan jarak jauh yang nantinya dikhawatirkan dapat mempengaruhi kualitas data yang digunakan sebagai bukti audit.

Selain berdampak kepada audit eksternal, pemeriksaan jarak jauh juga berpengaruh kepada audit internal karena situasi tersebut membuat audit internal harus mengalokasikan lebih banyak waktu untuk menyusun perencanaan audit jarak jauh dan untuk menyiapkan serta melakukan pengunggahan dokumen yang diminta auditor eksternal ke platform berbagi. Namun remote audit juga memberikan dampak positif kepada auditor seperti menghematnya biaya perjalanan audit. Selain itu juga menguntungkan apabila lokasi untuk kunjungan pemeriksaan merupakan lokasi yang bahaya apabila dilakukan kunjungan seperti wilayah 
yang terdampak pandemi tinggi dimana akses perjalanan juga dibatasi. Masalah lain mungkin akan muncul terutama mengenai kebenaran bukti audit.

Pandemi Covid-19 menyebabkan banyak perusahaan mengalami kebangkrutan sehingga mendorong perusahaan untuk melakukan manipulasi laba selama krisis berlangsung, yang membuat auditor harus menaikkan penerapan prosedur analitis dengan alasan bahwa prosedur analitis mempunyai biaya paling rendah dan cukup mudah untuk penghitungan (Rose et al. 2020).

Menurut (Halim 2018) prosedur analitis merupakan proses evaluasi informasi keuangan yang dilakukan dengan meninjau keterkaitan yang logis antara data keuangan dan non keuangan. Adanya ancaman terhadap risiko penipuan mengharuskan auditor untuk lebih maksimal dalam melakukan audit terutama dalam hal pengumpulan bukti audit. Bukti yang paling dipercaya adalah bukti yang secara langsung diperoleh auditor dari pihak di luar perusahaan yang bebas dan tidak terikat dengan pihak lain karena memberikan tingkat kepercayaan yang lebih tinggi jika dibandingkan dengan bukti yang didapatkan dari dalam perusahaan (Halim 2018). Namun disisi lain karena adanya pandemi Covid-19 mengakibatkan penggunaan formulir asli mengalami penurunan, seperti menurunnya penggunaan invoice asli sebagai dokumen pendukung saat terjadinya transaksi pembayaran, padahal diyakini lebih dapat dipercaya daripada invoice yang diperoleh dari surat elektronik ataupun media elektronik lainnya, sehingga hal ini menunjukkan bahwa strategi Work From Home dapat memberikan dampak terhadap kelengkapan dan keandalan bukti audit dan pada akhirnya dapat berpengaruh pada kualitas audit (KPMG 2020).

Munculnya pandemi merupakan suatu tantangan bagi auditor. Pasalnya meskipun kondisi seperti sekarang, auditor tetap harus menjaga kualitas audit yang dilaksanakan dan mendapatkan bukti audit yang akurat dan memadai sehingga dapat dimanfaatkan sebagai pendukung dari opini yang diberikan. Adanya PSBB yang berimbas pada adanya hambatan akses jalan dan kesiapan anggota audit membuat auditor harus mengeksplorasi prosedur audit, termasuk dalam bidang teknologi. Agar audit yang dilakukan saat ini dapat selesai dan memiliki kualitas yang tinggi, maka perlu adanya tambahan waktu yang akibatnya dapat berpengaruh terhadap jangka waktu pelaporan. Adanya kendala yang terjadi maka auditor harus mencermati mengenai standar audit relevan yang digunakan dan tetap menjaga komunikasi dengan pihak terkait.

\section{KESIMPULAN}

Pandemi yang muncul pada tahun 2019 memberikan dampak yang signifikan terhadap segala bidang, baik itu pendidikan, kesehatan ataupun ekonomi. Kebijakan social distancing yang bertujuan untuk mengurangi penyebaran Covid-19 ternyata berdampak pada proses audit yang dilakukan Kantor Akuntan Publik. Berdasarkan dari analisis yang dilakukan, adanya penurunan biaya audit dan time budget pressure mempengaruhi kualitas hasil audit yang telah dilaksanakan, hal ini karena mengakibatkan tekanan pada auditor. Begitupun dengan turunnya gaji staf audit yang mengakibatkan motivasi staf audit menurun dan pada akhirnya berpengaruh pada kualitas audit.

Dampak pandemi juga mengakibatkan turunnya laba pada perusahaan sehingga auditor mengalami kesulitan dalam menentukan kemampuan perusahaan untuk melanjutkan usahanya. Selain itu, melonjaknya kasus Covid-19 juga berdampak pada gagalnya program pelatihan yang telah disusun sebelumnya dalam rangka peningkatan kompetensi auditor serta kurangnya personel akibat terserang coronavirus sehingga berpengaruh terhadap kinerja kantor akuntan publik dan kualitas audit. Dengan situasi yang terjadi saat ini, memaksa auditor untuk melakukan proses audit jarak jauh (remote audit) yang berpengaruh pada kelengkapan dan keandalan bukti audit. Oleh karena itu, baik perusahaan klien ataupun perusahaan audit dianjurkan untuk memahami lebih dalam penggunaan teknologi untuk menunjang proses audit yang dilaksanakan. 


\section{SARAN}

Salah satu keterbatasan dari penelitian ini yaitu tidak dilakukan pengujian empiris apapun mengenai dampak pandemi covid-19 terhadap kualitas audit suatu perusahaan. Oleh karena itu diharapkan penelitian dimasa depan dapat menyertakan pengujian empiris dari dampak pandemi covid-19 terhadap biaya audit, gaji staf auditor, kelangsungan usaha, prosedur audit dan juga sumber daya manusia sehingga penelitian tersebut dapat melengkapi penelitian ini.

Karena dampak pandemi yang terus melonjak, auditor membutuhkan waktu tambahan dalam menyelesaikan proses audit agar kualitas audit yang dihasilkan dapat berkualitas tinggi. Oleh karena itu, peneliti menyarankan agar pemerintah ataupun pasar saham dapat memberikan kelonggaran waktu dalam hal pelaporan laporan keuangan. Selain itu, otoritas pajak juga dapat memberikan perpanjangan waktu dalam pembayaran pajak dan denda.

Dengan diberlakukannya PSBB memaksa auditor untuk melakukan audit jarak jauh (remote audit). Dengan metode audit jarak jauh, seluruh pemeriksaan audit dilakukan dengan bantuan teknologi. Oleh karena itu, baik perusahaan klien ataupun perusahaan audit harus berinvestasi lebih pada bidang teknologi agar audit jarak jauh dapat berjalan mulus dan keamanan data juga terjamin.

\section{REFERENSI}

Albitar, Khaldoon. 2020. "Auditing in Times of Social Distancing: The Effect of COVID-19 on Auditing Quality."

BAK UII. 2020. "Ternyata Fee Audit Berpengaruh Terhadap Kulaitas Audit Loooh !" 2020. https://bakuii.com/article-item/47.

Chen, Hanmei, Shaowen Hua, Zenghui Liu, and Mei Zhang. 2019. "Audit Fees, Perceived Audit Risk, and the Financial Crisis of 2008." Asian Review of Avccounting 27 (1). https://www.emerald.com/insight/publication/issn/1321-7348.

Deloitte. 2020. "Potensi Implikasi COVID-19 Bagi Sektor Asuransi.” 2020. https://www2.deloitte.com/uk/en/insights/economy/covid19/.

Diatmika, Nyoman Gede Arya, and Putu Ayu Pande Riani Savitri. 2020. "Pengaruh Time Budget Pressure, Locus of Control Dan Perilaku Disfungsional Audit Terhadap Kinerja Auditor (Studi Pada Kantor Akuntan Publik Indonesia)." Jurnal Ilmiah Akuntansi \& Bisnis Akuntansi 5 (2): 70-79.

Fitriyah, Noer, and Putu Purnama Dewi. 2018. "Time Pressure, Moralitas Dan Prosedur Audit." Jurnal IImiah Akuntansi \& Bisnis 3 (2): 133-44. file:///C:/Users/Made/Downloads/1073-3066-1-PB.pdf.

FRC. 2020. "Guidance on Audit Issues Arising from the Covid-19 (Coronavirus) Pandemic." 2020. https://www.frc.org.uk/news/march-2020-(1)/guidance-on-audit-issues-arisingfrom-the-COVID-19.

Halim, Abdul. 2018. AUDITING 1 Dasar-Dasar Audit Laporan Keuangan. Revisi. Yogyakarta: UPP STIM YKPN.

Hoopes, Jeffrey L, Kenneth J Merkley, Joseph Pacelli, and Joseph H Schroeder. 2018. "Audit Personnel Salaries and Audit Quality." Review of Accounting Studies 23 (3): 1096-1136.

IAPI. 2020a. "RESPONS AUDITOR ATAS PANDEMI COVID-19: Terhadap Laporan Keuangan, Prosedur Audit, Dan Pertimbangan Praktis Penunjang Kualitas Audit."

_. 2020b. "Respons Auditor Atas Pandemi Covid-19." 2020. https://iapior.id/lapi/detail/909.

JHU. 2021. "Global Tracking Map: COVID-19 Cases and Data Visualization." 2021. https://coronavirus.jhu.edu/map.html.

Jusup, Al. Haryono. 2014. Auditing (Pengauditan Berbasis ISA). Yogyakarta: Bagian Penerbitan Sekolah Tinggi Ilmu Ekonomi YKPN.

KPAP. 2021. "Tantangan Menjaga Kualitas Audit Di Masa Pandemi Covid-19." 2021. https://kpap.go.id/2021/03/berita-kpap/tantangan-menjaga-kualitas-audit-di-masapandemi-covid-19/. 
KPMG. 2020. “COVID-19: Potential Impact on Financial Reporting." 2020. https://home.kpmg/xx/en/home/insights/2020/03/covid-19-financial-reporting-resourcecentre.html.

Kurnia, Pipin, and Nanda Fito Mella. 2018. "Opini Audit Going Concern : Kajian Berdasarkan Kualitas Audit, Kondisi Keuangan , Audit Tenure, Ukuran Perusahaan , Pertumbuhan Perusahaan Dan Opini Audit Tahun Sebelumnya Pada Perusahaan Yang Mengalami Financial Distress Pada Perusahaan Manufaktur ( St." Jurnal IImiah Akuntansi Dan ... 6 (1): 105-22.

Lennox, Clive S., and Xi Wu. 2018. "A Review of the Archival." Accounting Horizon 32 (2): 1-35.

Litzenberg, Roy, and Carrie F Ramirez. 2020. "Remote Auditing for Covid-19 and Beyond."

Purwanto, Antonius. 2021. "Ekonomi Dunia Di Masa Pandemi Covid-19: Dari Dampak Hingga Proyeksi Pertumbuhan 2021-2022." Kompaspedia. 2021.

https://kompaspedia.kompas.id/baca/paparan-topik/ekonomi-dunia-di-masa-pandemicovid-19-dari-dampak-hingga-proyeksi-pertumbuhan-2021-2022.

Rose, Anna M, Jacob M Rose, Ikseon Suh, and Jay C Thibodeau. 2020. "Analytical Procedures: Are More Good Ideas Always Better for Audit Quality?" Behavioral Research in Accounting 32 (1): 37-49.

Saleem, Khalil SM Abu. 2021. "The Impact of the Coronavirus Pandemic on Auditing Quality In" 15 (4): 31-40.

Setiawan, Doni Agus. 2021. "Tingkatkan Kompetensi Auditor, Begini Strategi BPK." DDTC News. 2021. https://news.ddtc.co.id/tingkatkan-kompetensi-auditor-begini-strategi--bpk29963?page_y=1123.

Suryo, Medianto. 2017. "Pengaruh Time Budget Pressure Dan Risiko Audit Terhadap Kualitas Audit (Survey Pada Auditor Di Kantor Akuntan Publik Di Bandung)." Jurnal Riset Akuntansi Dan Keuangan 5 (1): 1325-36. https://doi.org/10.17509/jrak.v5i1.6757.

Suwandi, Eko Darmawan. 2021. "Kualitas Audit Perusahaan Pada Masa Pandemic Covid 19 ( Studi Literatur )" 14 (1): 27-36.

Syafnidawaty. 2020. "Literature Review." 2020. https://raharja.ac.id/2020/10/13/literaturereview/.

WHO. 2020. "Coronavirus Disease (COVID-19)." Health Topics. 2020.

https://www.who.int/health-topics/coronavirus\#tab=tab_1. 